\title{
Pengaruh Kedinamisan Suatu Kelompokerhadap Fungsi Kelompok (Studi Kasus Pada Kelompok Perikanan di Kabupaten Bekasi Provinsi Jawa Barat)
}

\author{
Group Dynamics Inpluence to Grouf Function \\ (Case Study Fisheries Group at Bekasi Distrik East Java Province) \\ Abdul Hanan ${ }^{\bowtie}$ \\ Sekolah Tinggi Perikanan, Jurusan Penyuluhan Perikanan \\ Jalan Cikaret Nomor 1 Bogor 16001, Jawa Barat
}

Diterima: 21 Januari 2015; Disetujui: 2 Juni 2015

\begin{abstract}
Abstrack
Hasil penelitian memperlihatkan bahwa usia kelompok 63,3\% pada rata-rata 3,7 tahun, kelas kelompok menunjukkan $43,3 \%$ berada pada kelas yang tinggi (utama), namun yang berada di kelas pemula juga persentasenya mencapai 36,6\%. Jika dirata-ratakan maka kelas kelompok di Kabupaten bekasi pada kelas madya. Sebanyak $80 \%$ dari kelompok perikanan, jumlah anggota dengan rata-rata 25 orang. Unsur dinamika kelompok pada interval 53,4 \% - 93,3\%. Namun demikian pada unsur "Suasana Kelompok" tidak ada kelompok yang katagorinya baik, dan pada unsur dinamika kelompok "Keberhasilan kelompok tidak ada kelompok dengan katgori rendah. Nilai Korelasi Faktor Internal kelompok dan tiga fiungsi kelompok memperlihatkan unsur "tekanan pada kelompok" berhubungan erat dengan fungsi kelompok sebagai unir produksi ( 0,378), Sedangkan unsur Keberhasilan kelompok ternyata berhubungan erat dengan berfungsi baiknya kelompok sebagai kelas belajar $(0,400)$ dan berhungan sangat erat pada unit kerjasama $(0,771)$. Nilai Korelasi delapan unsur dinamika kelompok hanya unsur" pengembangan dan pemeliharaan kelompok yang berhubungan erat dengan usia kelompok $(0,393)$. Sedangkan usur dinamika kelompok lainnya tidak begitu erat hubunganya dengan berfungsi atau belum berfungsinya suatu kelompok perikanan.Nilai Korelasi Antar Unsur Dinamika Kelompok memperlihatkan bahwa tujuan kelompok berhubungan sangat erat dengan struktur kelompok $(0,378)$ dan unsur pengembangan dan pemeliharaan kelompok $(0,503)$. Sedangkan unsur pengembangan kelompok berhubungan erat dengan terbentuknya suasana kelompok yang kondusif $(0,422)$ Nilai Korelasi Antar Fungsi Kelompok menunjukkan bahwa bila kelompok sebagai unit usaha bersama berfungsi dengan baik, maka fungsi sebagai kelas belajarpun akan berfungsi dengan baik, dan demikian sebaliknya. Sedangkan fungsi kelompok yang lain tetap masih ada hubungan yang timbal balik namum pada kasusu kelompok perikanan di Kabupoaten bekasi belum memperlihatkan keeratan yang kuat antar fungsi kelompok sebagai kelas belajar dengan sebagai unit produksi.
\end{abstract}

Kata Kunci; Dinamika Kelompok, Fungsi kelompok

\begin{abstract}
Abstrak
The results showed that the age group of $63.3 \%$ at an average of 3.7 years, the class group showed $43.3 \%$ in the high grade (primary), but that was in a beginner class is also the percentage reached $36.6 \%$. In average the class groups in Bekasi Regency on middle class. As many as $80 \%$ of the group of fisheries, the number of members with an average of 25 people. Elements of group dynamics at intervals of 53.4\% - 93.3\%. However, the element of "Atmosphere Group" no group katagorinya good, and the element of group dynamics "group's success was no group with the low category. Value Correlation Factors Internal groups and three function groups showed elements of "pressure groups" is closely linked to the function of the group as unit production (0.378), while the element of group's success turned out to be closely linked to the well-functioning group as classroom learning $(0,400)$ and berhungan very closely on cooperation unit (0.771). The correlation value of the eight elements of group dynamics only elements of "the development and maintenance of a group that is closely related to the age group (0.393). While the other group dynamics usur not so tight relationship with the functioning or not functioning of a fisheries group. Value Correlation Between Elements of Group Dynamics shows that the purpose of the group is closely related to the structure of the group (0.378) and elements of the development and maintenance group (0.503). While the element of group development is closely related to the formation of an atmosphere conducive group (0.422) Correlation Between Function Value Group showed that when the group as a joint venture unit to function properly, it functions as a class belajarpun will function well, and vice versa. While the function of the other groups still there is a relationship of reciprocal However the retrospective case series in Kabupoaten bekasi fisheries groups have not shown a strong cohesion between group functions as classroom learning with a production unit.
\end{abstract}

Key Word: Group Dynamics; Group Function

$\triangle$ Penulis korespondensi

Alamat surel: abdulhanan278@gmail.com

Jurnal Penyuluhan Perikanan dan Kelautan 


\section{Pendahuluan}

Latar Belakang

Sebagai mahluk sosial, manusia harus berkelompok. Kelompok merupakan sasaran kinerja dari seorang penyuluh perikanan sebagaimana tertuang dalam Per Men Pan 19 2008. Tantang Jabatan Penyuluh Perikanan dan Angka Kreditnya. Dalam rangka pedoman pembinaan pada kelompok tersebut sudah diatur dalam Pedoman Penumbuhan dan Pengembagan Kelembagaan Pelaku utama Perikanan. Penyuluhan Perikanan adalah proses pembelajaran bagi pelaku utama serta pelaku usaha agar mereka mau dan mampu menolong dan mengorganisasikan dirinya dalam mengakses informasi pasar, teknologi, permodalan, dan sumberdaya lainnya sebagai upaya untuk meningkatkan produktivitas, efisiensi usaha, pendapatan, dan kesejahteraannya, serta meningkatkan kesadaran dalam pelestarian fungsi lingkungan hidup. Karena tujuan penyuluhan jangka panjang adalah terjadi peningkatan taraf hidup masyarakat, maka hal ini hanya dapat dicapai apabila masyarakat telah melakukan langkah-langkah sebagai berikut :

a. Better Fisheries, mau dan mampu mengubah cara-cara usaha perikanan yang lebih baik,

b. Better Business, berusaha yang lebih menguntungkan, mau dan mampu menjauhi para pengijon, lintah darat, dan melakukan teknis pemasaran yang benar,

c. Better living, hidup lebih baik dengan mampu menghemat, tidak berfoya-foya dan setelah berlangsungnya masa panen, bisa menabung, bekerja sama memperbaiki hygiene lingkungan, dan mampu mencari alternatif lain dalam hal usaha, misal mendirikan industri rumah tangga yang lain dengan mengikutsertakan keluarganya guna mengisi dan mengotimalkan tenaga, pemikiran, peluang pasar, ide kreatif yang dikembangkan untuk mengisi kekosongan waktu selama menunggu panen berikutnya

Permasalahan; dalam penelitian ini; fungsi kelompok belum berjalan sesuai harapan karena unsur-unsur dinamika kelompok belum dijalankan, lemahnya dinamika kelompok karena Kohesi/persatuan, Motif/dorongan, Struktur, Pimpinan dan Perkembangan kelompok yang belum baik, Kompetensi pembina kelompok belum sepenuhnya paham pentingnya dinamika kelompok. Adapun tujuan Penelitian; Menjelaskan pengaruh unsur dinamika terhad fungsi kelompok sebagai kelas belajar, Menjelaskan pengaruh unsur dinamika terhad fungsi kelompok sebagai wadah kerjasama produksi, Menjelaskan pengaruh unsur dinamika terhad fungsi kelompok sebagai unit usaha bersama. Kegunaan Penelitian; Memberikan kontribusi bagi pengembangan ilmu dan teknologi yang berkaitan dengan kelompok, Memberikan masukan kepada stakeholder terkait dengan kebijakan pembinaan kelompok

\section{Tinjauan Pustaka}

\section{Pengertian Kelembagaan Pelaku Utama}

Kelembagaan pelaku utama perikanan adalah kumpulan para pelaku utama yang terdiri dari nelayan, pembudi daya ikan, dan pengolah ikan yang terikat secara informal atas dasar keserasian dan kebutuhan bersama serta di dalam lingkungan pengaruh dan pimpinan seorang ketua kelompok pelaku utama kelautan dan perikanan. Kelembagaan pelaku utama kegiatan perikanan dapat berbentuk kelompok, gabungan kelompok, asosiasi, atau korporasi. Kelembagaan pelaku utama lebih umum orang menyebutnya dengan kelompok, walaupun para ahli memandang pengertian dari kelompok dari berbagai sudut yang berbeda. Walgino (Hariadi, 2011) menyebutkan pengertian kelompok dapat dipandang dari segi persepsi, motivasi, tujuan, 
interdependensi dan juga dari sudut intekasi. Berdasarkan segi persepsi melihat kelompok pada asusmsi bahwa anggotanya sadar dan memeiliki persepsi kolektif tentang hubungan diantara para anggotanya. Kelompok atas dasar motivasi bahwa kelompok adalah kumpulan individu yang keberadannya sebagai kumpulan yang memberikan reward kepada individuindividu. Kelompok atas dasar tujuan yaitu kelompok sebagai satu kesatuan yang terdiri dari dua orang atau lebih yang melakukan kontak hubungan untuk satu tujuan tertentu. Kelompok atas dasar interdependensi adalah klompok sebagai keumpulan orang yang saling bergantung satu dengan yang lainnya. Sedangkan kelompok atas dasar interkasi, bahwa kelompok adalah dua orang atau lebih yang berinteraksi satu dengan yangh lain dan saling mempengaruhi.

\section{Fungsi Kelembagaan Pelaku Utama Perikanan}

Peraturan Menteri Kelautan dan Perikanan Nomonr 14 tahun 2011, menyebutkan bahwa ada 8 (delapan) fungsi kelompok yaitu:

a. Wadah Proses Pembelajaran

Sebagai wadah proses pembelajaran, kelembagaan pelaku utama perikanan merupakan media interaksi belajar antar pelaku utama dari anggota kelompoknya.

b. Wahana Kerjasama

Sebagai wahana kerjasama, kelembagaan pelaku utama perikanan merupakan cerminan dari keberadaan suatu kelompok. Kelembagaan pelaku utama perikanan harus dapat berfungsi sebagai wadah kerjasama antar pelaku utama dalam upaya mengembangkan kelompok dan membina kehidupanpelaku utama.

c. Unit Penyedia Sarana dan Prasarana Produksi Perikanan

Kelembagaan pelaku utama perikanan sebagai unit penyedia sarana dan prasarana, erat hubungannya dengan fungsi unit produksi perikanan. Misalnya dalam sebuah produksi budidaya ikan gurame, kelompok dapat berperan sebagai penyedia benih ataupun sarana produksi lainnya.

d. Unit Produksi Perikanan

Kelompok pelaku utama perikanan sebagai unit produksi, erat hubungannya dengan fungsi wadah kerjasama. Misalnya kelompok pembudidaya ikan gurame, dalam pengadaan sarana produksi, perkreditan, dan pemasaran hasil, sehingga dengan melaksanakan kegiatan produksi secara bersama-sama akan lebih efisien. e. Unit Pengolahan dan Pemasaran

Kelompok pelaku utama perikanan sebagai unit pengolahan dan pemasaran, erat hubungannya dengan fungsi wadah kerjasama. Misalnya kelompok pengolah hasil perikanan, dalam melaksanakan kegiatan pengolahan dan pemasaran hasil secara bersama-sama akan lebih efisien serta dapat menjamin kestabilan harga produk.

\section{f. Unit Jasa Penunjang}

Kelembagaan pelaku utama perikanan juga dapat berfungsi sebagai sebuah unit usaha yang mengelola usaha diluar usaha pokoknya seperti jasa penyewaan, jasa percontohan, jasa konsultasi, dan lain-lain.

g. Organisasi Kegiatan Bersama

Kelembagaan pelaku utama berfungsi sebagai organisasi kegiatan bersama dimana pelaku utama akan belajar mengorganisasi kegiatan secara bersama-sama melalui pembagian dan pengkoordinasian pekerjaan dengan mengikuti tata tertib sebagai hasil kesepakatan bersama.

h. Kesatuan Swadaya dan Swadana

Kelembagaan pelaku utama perikanan sebagai kesatuan swadaya dan swadana merupakan kelembagaan yang mandiri, baik 
dalam hal penyelesaian masalah bersama maupun dalam penguatan dan pengembangan modal usaha anggota, misalnya melakukan pemupukan modal bersama untuk menyediakan modal bagi anggotanya melalui penumbuhan budaya menabung, iuran, dan sebagainya. Dengan demikian, anggota mendapatkan kemudahan dalam mendapatkan modal usaha, bermitra dengan lembaga keuangan, serta mempermudah dalam akses pemasarannya.

\section{Dinamika Kelompok}

Kurt Lewin dalam Hariadi (2011) merumuskan bahwa perilaku orang dipengaruhi oleh keadaan diri pribadi/personality dan lingkungannya, yang kemudian mengembangkannya kedalam kelompok dan selanjutnya dikenal dengan teori dinamika kelompok. Selanjutnya disebutkan bahwa dinamika kelompok merupakan gerak kelompok karena kekuatan-kekuatan, baik yang terjadi di dalam maupun luar kelompok, saling mempengaruhi dalam proses mencapai tujuan kelompok. Istilah dinamika kelompok berasal dari bahasa inggris "dynamics" yang berarti mempunyai gairah atau semangat untuk bekerja. Dengan demikian pengertian dinamika kelompok ditinjau dari istilah mengandung arti yaitu berkelompok yang selalu memiliki gairah dan semangat untuk bekerja. Sisi lain dinamika berarti adanya interaksi, saling mempengaruhi dan interdependensi antara anggota kelompok satu sama lain secara timbal balik diantara anggota kelompok dengan kelompok secara keseluruhan. Menurut Hariadi (2000) dijelaskan bahwa; Dinamika berarti tingkah laku warga yang satu secara langsung mempengaruhi warga yang lain secara timbal balik. Dinamika berarti adanya interaksi dan interdependensi antara anggota klpk yang satu dgn anggota yang lain secara timbal balik dan antara anggota dengan kelompok secara keseluruhan. Selanjutnya disebutkan bahwa selama ada kelompok, semangat kelompok (group spirit) terus-menerus hidup dalam kelompok itu. Dan setiap saat kelompok yang bersangkutan dapat berubah. Dinamika Kelompok merupakan suatu kelompok yang terdiri dari dua atau lebih individu yang memiliki hubungan psikologis secara jelas antara anggota satu dengan yang lain dan berlangsung dalam situasi yang dialami (Shaw, 1979). Sedangkan dalam kamus Besar Bahasa Inonesia, dinamika kelompok adalah gerak atau kekuatan yang dimiliki sekumpulan orang dalam masyarakat yang dapat menimbulkan perubahan dalam tata hidup masyarakat bersangkutan. Hubungan psikologis yang jelas antara anggota kelompok yang satu dengan yang lain. Dinamika kelompok berkaitan erat dengan tujuan dan fungsi penyelenggaraan Penyuluhan Perikanan. Kelompok harus bisa produktif, harus bisa menghasilkan sesuatu, bermanfaat bagi anggotanya. Agar kelompok produktif, kelompok harus dinamis. Untuk bisa dinamis, unsur-unsur dinamika sebagai kekuatan kelompok tersebut harus terpenuhi. Unsur-unsur dinamika kelompok tersebut adalah;

\section{Tujuan Kelompok}

Tujuan kelompok dapat diartikan sebagai gambaran yang diharapkan angota yang akan dicapai oleh kelompok. Tujuan kelompok harus jelas dan diketahui oleh seluruh anggota. Untuk mencapai tujuan kelompok tersebut diperlukan aktivitas bersama oleh para anggota. Hubungan antara tujuan kelompok dengan tujuan anggota bisa : a) sepenuhnya bertentangan, b) sebagian bertentangan, c) netral, d) searah dan e) identik. Dengan demikian bentuk hubungan a tidak menguntungkan dan bentuk d adalah yang paling baik. Dengan demikian diperlukan adanya dinamikan dalam pengembangan kelompok. 
Struktur Kelompok

Struktur kelompok adalah bentuk hubungan antara individu-individu dalam kelompok sesuai posisi dan peranan masingmasing. Struktur kelompok harus sesuai/ mendukung tercapainya tujuan kelompok.

Yang berhubungan dengan struktur kelompok yaitu:

a. Struktur Komunikasi

b. Struktur Tugas Atau Pengambilan Keputusan,

c. Struktur Kekuasaan Atau Pengambilan Keputusan

d. Sarana Terjadinya Interaksi

Fungsi Tugas

Fungsi tugas adalah segala kegiatan yang harus dilakukan kelompok dalam rangka mencapai tujuan. Secara keseluruhan fungsi ini sebaiknya dilakukan dengan kondisi menyenangkan, dengan kondisi yang menyenangkan dapat menjamin fungsi tugas ini dapat terpenuhi. Kriteria yang dipergunakan pada fungsi tugas ini terpenuhi atau tidak adalah terdapatnya:

a. Fungsi Memberi Informasi

b. Fungsi Koordinasi

c. Fungsi Memuaskan Anggota

d. Fungsi Berinisiatif

e. Fungsi Mengajak Untuk Berpartisipasi,

f. Fungsi Menyelaraskan

Mengembangkan Dan Membina Kelompok

Mengembangkan dan membina kelompok dimaksudkan sebagai usaha mempertahankan kehidupan kelompok, kehidupan berkelompok dapat dilihat dari adanya kegiatan, yaitu:

a. Mengusahakan/mendorong agar semua anggota kelompok ikut berpartisipasi dalam setiap kegiatan kelompok. Tersedianya fasilitas, b. Mengusahakan/ mendorong menumbuhkan kegiatan

c. Menciptakan norma kelompok. Norma kelompok ini adalah sebagai acuan anggota kelompok bertindak,

d. Mengusahakan adanya kesempatan anggota baru, baik untuk menambah jumlah maupun mengganti anggota yang keluar,

e. Berjalannya proses sosialisasi. Untuk mensosialisasikan adanya anggota baru adanya norma kelompok adanya kesepakatan, dan sebagainya

\section{Kekompakan Kelompok}

Kekompakan kelompok menunjukkan tingkat rasa untuk tetap tinggal dalam kelompok, hal ini dapat berupa : loyalitas, rasa memiliki, rasa keterlibatan, dan keterikatan.

Terdapat enam faktor yang mempengaruhi kekompakan kelompok yaitu:

a. Kepemimpinan Kelompok

b. Keanggotaan Kelompok

c. Nilai Tujuan Kelompok

d. Homogenitas Angota Kelompok

e. Keterpaduan Keiatan Kelompok

f. Jumlah Anggota Kelompok

Suasana Kelompok

Suasana kelompok adalah keadaan moral, sikap dan perasaan bersemangat atau apatis yang ada dalam kelompok, suasana kelompok yang baik bila anggotanya merasa saling menerima, saling menghargai, saling mempercayai dan bersahabat.

Faktor-faktor yang mempengaruhi suasana kelompok adalah:
a. hubungan antar anggota
b. kebebasan berpartisipasi
c. lingkungan fisik yang mendukung. 
Tekananan pada Kelompok

Tekanan pada kelompok dimaksudkan adalah adanya tekanan-tekanan dalam kelompok yang dapat menimbulkan ketegangan, dengan adanya ketegangan akan timbul dorongan untuk mempertahankan tujuan kelompok. Tekanan kelompok yan cermat, dan terukur akan dapat mendinamiskan kelompok, bila tidak justru akan berakibat sebaliknya.

\section{Efektifitas Kelompok}

Efektifitas kelompok adalah keberhasilan dalam melaksanakan tugas-tugas kelompok dalam mencapai tujuan. Semakin banyak tujuan yang dapat dicapai, semakin banyak keberhasilan, anggota kelompok akan semakin puas. Bila anggota kelompok merasa puas kekompakan dan kedinamisan kelompok akan semakin kuat.

Hipotesis Penelitian

1. Karakteristik Internal mempengaruhi fungsi kelompok

2. Dinamika kelompok mempengaruhi fungsi kelompok sebagai unit kelas belajar

3. Dinamika kelompok mempengaruhi sebagai fungsi wadah unit produksi

4. Dinamika kelompok mempengaruhi sebagai fungsi wadah kerjasama usaha

Metodologi Penelitian

Penelitian berupa kasus dengan sifat korelatif deskriptif. Bertujuan menjelaskan faktor-faktor yang berhubungan dengan terbentuknya jenis kelompok (kerlinger, 2002). Penelitian dilakukan pada Bulan Maret sampai April 2015, pada 35 kelompok perikanan yang ada di Kabupten Bekasi. Data dikumpulkan melalui daftar pertasnyaan, wawancara mendalam, dan kajian terhadap data sekunder. Analisa data dilakukan secara deskriftif, analisa kualitatif dilakukan untuk semua tujuan penelitian, analisa kuantitatif dilakukan untuk menguji hipotesis yang diajukan. karakteristik internal dan karakteristik eksternal serta karakteristik inovasi diukur dengan menggunakan distribusi frekuensi dan nilai tengah. Untuk mengetahui hubungan antar peubah dilakukan analisis hubungan dengan koefisien korelasi Spearman, sebagai uji korelasi bagi data non parametrik.

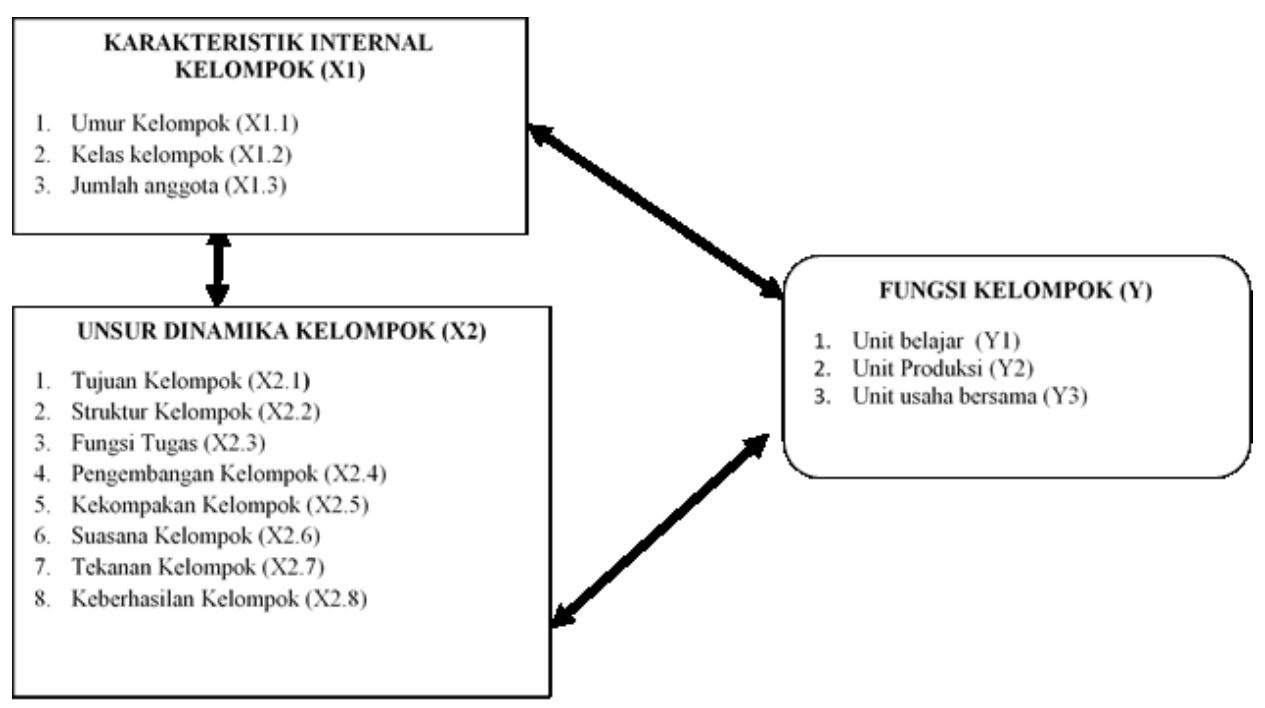

Gambar 1. Kerangka Pikir Penelitian 


\section{Hasil dan Pembahasan}

Karakteristik responden

Responden dalam penelitian ini adalah kelompok pelaku utama perikanan yang dimbil secara rendom. Karakteriktik internal responden penelitian yaitu umur kelompok, Tingkat Kelas Kelompok, jumlah anggota yang dianalisis dengan pengkatagorian, persentase, interval dan rata-rata, seperti pada Tabel 1.

Pada Tabel 1 memperlihatkan bahwa usia kelompok 63,3\% pada kisaran usia sedang (1,2 6,2) tahun dengan rata-rata 3,7 tahun, Kisaran umur kelompok tersebut merupakan usia produkstif dalam berkelompok, dalam arti seharunya dapat memperlihat kedinamisan kelompok yang bisa diamamti dari segi fungsi kelompoknya. Namun demikian faktor pembinaan yang kontinyu dari pemerintah (penyuluh) terhadap kelompok juga sangat berpengaruh terhadap kedinam,isan kelompok tersebut yang akan meningkatkan efektifitas fungsi-fungsi kelompok. Dari segi tingkat kelas kelompok menunjukkan $43,3 \%$ berada pada kelas yang tinggi (utama), namun yang berada di kelas pemula juga hampir persentasenya yaitu mencapai $36,6 \%$, Jika dirata-ratakan maka kelas kelompok di Kabupaten bekasi pada kelas madya. Kelas kelompok seharusnya juga telah berfungsinya kelompok dengan baik. Margono menjelaskan seringkali kelas kelompok hanya sebagai administrasi untuk tujuan diluar tujuan dari berkelomopok itu sendiri. Jumalah anggota kelompok yang terdata menunjukkan bahwa $80 \%$ jumlah anggota tiap kelompok katagorinya cukup (antara $8-42$ orang) dengan rata-rata 25 orang. Hal tersebut sudah sesuai dengan pedoman bahwa maksimal jumlah anggota kelompok 30 orang. Margono (1989) mengemukakan bahwa kerja sama merupakan kemampuan untuk menjalin hubungan dengan orang lain yang menjadi bagian dari suatu kelompok dalam melaksanakan suatu tugas. Seloanjutnya dikemukakan bahwa dalam bekerja sama harus bisa menerima perbedaan-perbedaan yang ada pada setiap orang. Dalam hal ini, seseorang harus bisa memperlakukan orang yang berbeda dengan kita respek atau menghormatinya dan memiliki hubungan pertemanan dengan orang yang berbeda. Hariadi mengemukakan bahwa kerja sama (tim) merupakan salah satu unsur fundamental dalam TQM. Tim merupakan kelompok orang yang memiliki tujuan bersama. Faktor-faktor yang mendasari perlunya dibentuk tim-tim dalam suatu perusahaan adalah (1) saling ketergantungan, (2) perluasan tugas, (3) penjajaran (4) bahasa yang umum, (5)

Tabel 1. Sebaran Karakteriktik Internal

\begin{tabular}{|c|c|c|c|c|c|}
\hline No & KARAKTERISTIK & KATAGORI & PERSENTASE $(\mathbf{N}=\mathbf{3 0})$ & INTERVAL & RATA-RATA \\
\hline 1 & USIA KELOMPOK & $\begin{array}{ll}\text { MUDA } & (<1,2 \mathrm{TH}) \\
\text { SEDANG } & (1,2-6,2 \mathrm{TH}) \\
\text { TUA } & (>6,2 \mathrm{TH})\end{array}$ & $\begin{array}{l}\text { (8) } 26,7 \% \\
\text { (19) } 63,3 \% \\
\text { (3) } 10 \%\end{array}$ & $1-11 \mathrm{TH}$ & $3,7 \mathrm{TH}$ \\
\hline 2 & KELAS KELOMPOK & $\begin{array}{l}\text { RENDAH (1) } \\
\text { SEDANG (2) } \\
\text { TINGGI }\end{array}$ & $\begin{array}{l}\text { (11) } 36,7 \% \\
\text { (6) } 20 \% \\
\text { (13) } 43,3 \%\end{array}$ & $1-3$ & 2 \\
\hline 3 & JUMLAH ANGGOTA & $\begin{array}{l}\text { SEDIKIT }(<8) \\
\text { CUKUP }(8-42) \\
\text { BESAR }(>42)\end{array}$ & $\begin{array}{l}\text { (5) } 16,7 \% \\
\text { (8) } 20 \% \\
\text { (1) } 3,3 \&\end{array}$ & $7-50$ & $25 \mathrm{ORG}$ \\
\hline
\end{tabular}


keterampilan pemecahan masalah, (8) keterampilan menangani konflik, (9) penilaian / tindakan, dan (10) perayaan.

Pada Tabel 2 memperlihatkan bahwa ke delapan unsur kelompok pada kelompok perikanan di Kabupaten Bekasi pada interval $53,4 \%-93,3 \%$. Namun demikian pada unsur dinamika kelompok "Suasana Kelompok" tidak ada kelompok yang katagorinya baik, dn pada unsur dinamika kelompok "Keberhasilan kelompok tidak ada kelompok dengan katori rendah. Tujuan kelompok dapat diartikan sebagai gambaran yang diharapkan angota yang akan dicapai oleh kelompok. Tujuan kelompok harus jelas dan diketahui oleh seluruh anggota. Untuk mencapai tujuan kelompok tersebut diperlukan aktivitas bersama oleh para anggota. Hubungan antara tujuan kelompok dengan tujuan anggota bisa :
a. sepenuhnya bertentangan
b. sebagian bertentangan, c)
c. netral
d. searah dan
e. identik.

Dengan demikian bentuk hubungan a tidak menguntungkan dan bentuk d adalah yang paling baik.

Struktur kelompok adalah bentuk hubungan antara individu-individu dalam kelompok sesuai posisi dan peranan masingmasing. Struktur kelompok harus sesuai/mendukung tercapainya tujuan kelompok. Fungsi tugas adalah segala kegiatan yang harus dilakukan kelompok dalam rangka mencapai tujuan. Secara keseluruhan fungsi ini sebaiknya dilakukan dengan kondisi menyenangkan, dengan kondisi yang menyenangkan dapat menjamin fungsi tugas ini dapat terpenuhi.

Tabel 2. Sebaran Karakteriktik Dinamika Kelompok

\begin{tabular}{|c|c|c|c|c|c|}
\hline No & $\begin{array}{c}\text { KARAKTERISTIK DINAMIKA } \\
\text { KELOMPOK }\end{array}$ & KATAGORI & $\begin{array}{c}\text { PERSENTASE } \\
(\mathrm{N}=30)\end{array}$ & INTERVAL & RATA2 \\
\hline \multirow[t]{3}{*}{1} & Tujuan Kelompok & $R=5$ & $16,7 \%$ & & \\
\hline & & $S=22$ & $73,3 \%$ & 1- 3,4 & 2,3 \\
\hline & & $\mathrm{T}=31$ & $20 \%$ & & \\
\hline \multirow[t]{3}{*}{2} & Strulktur Kelompok & $R=5$ & $16,7 \%$ & & \\
\hline & & $S=18$ & $60,0 \%$ & $1,5-3,5$ & 2,53 \\
\hline & & $\mathrm{T}=7$ & $23,3 \%$ & & \\
\hline \multirow[t]{3}{*}{3} & Fungsi Tugas & $R=3$ & $10,0 \%$ & & \\
\hline & & $\mathrm{S}=25$ & $83,3 \%$ & $1,6-3,2$ & 2,53 \\
\hline & & $\mathrm{T}=2$ & $6,7 \%$ & & \\
\hline \multirow[t]{3}{*}{4} & Pengembangan Kelompok & $R=5$ & $16,7 \%$ & & \\
\hline & & $S=19$ & $63,3 \%$ & $1,5-3,5$ & 2,40 \\
\hline & & $\mathrm{T}=6$ & $20,0 \%$ & & \\
\hline \multirow[t]{3}{*}{5} & Kekompakan Kelompok & $R=5$ & $16,7 \%$ & & \\
\hline & & $S=19$ & $66,3 \%$ & $1,5-3,7$ & 2,70 \\
\hline & & $\mathrm{T}=6$ & $17,0 \%$ & & \\
\hline \multirow[t]{3}{*}{6} & Suasana Kelompok & $\mathrm{R}=4$ & $13,3 \%$ & & \\
\hline & & $S=26$ & $86,7 \%$ & $1,7-4$ & 3,22 \\
\hline & & $\mathrm{T}=0$ & 0 & & \\
\hline \multirow[t]{3}{*}{7} & Tekanan Kelompok & $\mathrm{R}=7$ & $23,3 \%$ & & \\
\hline & & $S=16$ & $53,4 \%$ & 02-Apr & 3,23 \\
\hline & & $\mathrm{T}=7$ & $23,3 \%$ & & \\
\hline \multirow[t]{3}{*}{8} & Keberhasilan Kelompok & $\mathrm{R}=0$ & 0 & & \\
\hline & & $S=28$ & $93,3 \%$ & $2-4$ & 2,70 \\
\hline & & $\mathrm{T}=2$ & $6,7 \%$ & & \\
\hline
\end{tabular}


Mengembangkan dan membina kelompok dimaksudkan sebagai usaha mempertahankan kehidupan kelompok, kehidupan berkelompok dapat dilihat dari adanya kegiatan, yaitu: Mengusahakan/mendorong agar semua anggota kelompok ikut berpartisipasi dalam setiap kegiatan kelompok.

Kekompakan kelompok menunjukkan tingkat rasa untuk tetap tinggal dalam kelompok, hal ini dapat berupa : loyalitas, rasa memiliki, rasa keterlibatan, dan keterikatan. Terdapat enam faktor yang mempengaruhi kekompakan kelompok yaitu: Kepemimpinan Kelompok, Keanggotaan Kelompok, Nilai Tujuan Kelompok, Homogenitas Angota Kelompok, Keterpaduan Keiatan Kelo, Jumlah Anggota Kelompok. Suasana kelompok adalah keadaan moral, sikap dan perasaan bersemangat atau apatis yang ada dalam kelompok, suasana kelompok yang baik bila anggotanya merasa saling menerima, saling menghargai, saling mempercayai dan bersahabat. Tekanan pada kelompok dimaksudkan adalah adanya tekanantekanan dalam kelompok yang dapat menimbulkan ketegangan, dengan adanya ketegangan akan timbul dorongan untuk mempertahankan tujuan kelompok. Tekanan kelompok yan cermat, dan terukur akan dapat mendinamiskan kelompok, bila tidak justru akan berakibat sebaliknya. Efektifitas kelompok adalah keberhasilan dalam melaksanakan tugastugas kelompok dalam mencapai tujuan. Semakin banyak tujuan yang dapat dicapai, semakin banyak keberhasilan, anggota kelompok akan semakin puas. Bila anggota kelompok merasa puas kekompakan dan kedinamisan kelompok akan semakin kuat. Berdasarkan uraian di atas Margono (1989) kalau sebuah kelompok unsur dinamika kelompoknya bagus maka berkorelasi dengan efektifnya dari fungsifungsi kelompok tersebut.

Berdasarkan hasil analisis seperti pada Tabel 3, menunjukkan bahwa dari ketiga fungsi kelompok yang dianalisis, tidak ada satupun kelompok perikanan yang menjalankan fungsi sebagai unit berlajar pada katagori baik. Sebanyak $80 \%$ kelompok perikanan di Kabupaten Bekasi menjalankan fungsi kelomp0k sebagai unit belajar pada katagori cukup baik, dan hanya $20 \%$ jumlah kelompok yang katogori menjalankan fungsi unit belajarnya. Pada menjalankan fungsi kelompok sebagai Unit produksi $40 \%$ kelompok belum menjalankan fungsi tersebut dengan baik (rendah), dan sisanya sebanyak 60\% pada katagori cukup baik. Dengan demikian belum ada satupun kelompok dengan

Tabel 3. Sebaran Karakteriktik Fungsi Kelompok

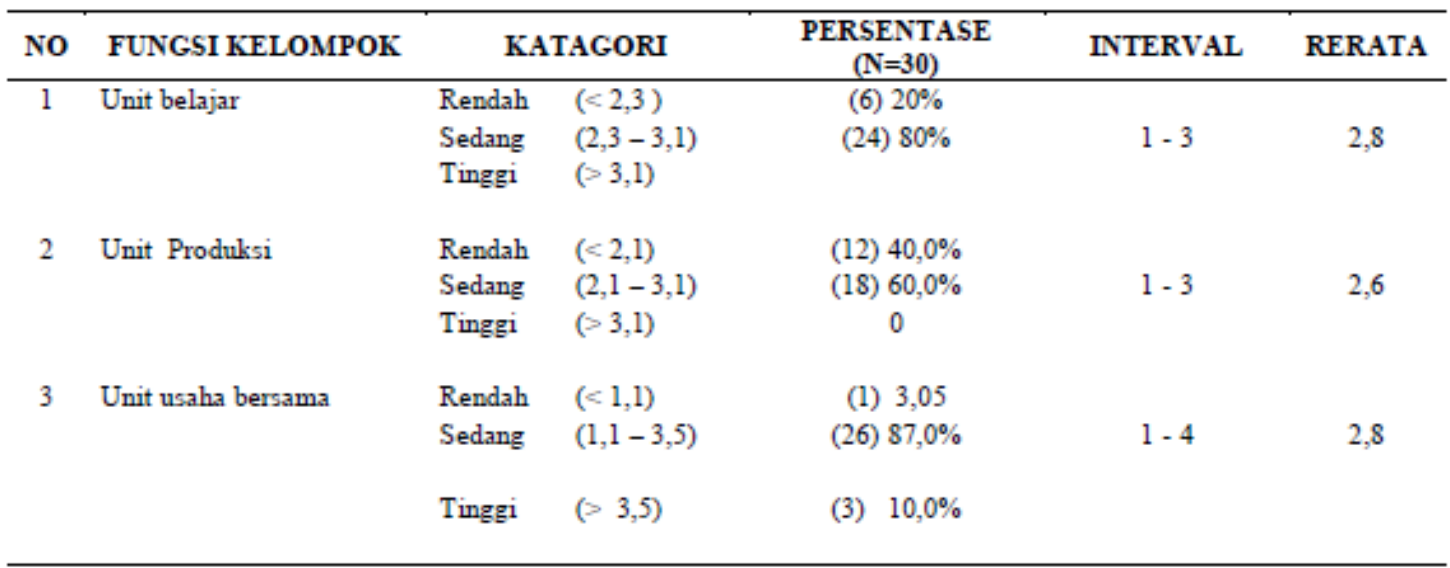


katagori menjalankan fungsinya dengan baik. Fungsi kelompok sebagai unit usaha bersama ssudah ada $10 \%$ dari jumlah kelompok yang katagorinya sudah baik dalam menjalankan fungsi tersbut, sedangkan yang katagorinya rendah masih ada 3\% dan sisanya sebanyak $87 \%$ pada katagori cukup baik. Menurut Hariadi (2011) Keberhasilan kelompok sebagai unit belajar dipengaruhi oleh faktor sikap terhadap profesinya, interkasi anggota kelompok, kohesi anggota kelompok, norma kelompok, dan penyuluh, Sedangkan keberhasilan kelompok sebagai unit kerjasama dipengaruhi oleh faktor interkasi anggota, norma kelompok, penyuluh dan pembinaan pamong desa. Keberhasilan kelompok sebagai unit produksi dipengaruhi oleh faktor self efficacy (keyakinan mampu berhasil), interkasi anggota, dan pembinaan oleh pamong desa. Sedangkan keberhasilan kelompok sebagai unit usaha dipengaruhi oleh faktor self efficacy, interkasi anggota dan gaya kempemimpinan ketua kelompok. Hal tersebut sejalan juga yang disampaikan Pranoto (2006)

Pada tabel 4. Terlihat bahwa faktor internal kelompok yang meliputi: umur kelompok jumlah anggota kelompok, tidak ada yang berhubungan erat dengan fungsi kelompok baik sebagai kelas belajar, unit produksi, dan unit usaha bersama. Sebagai wadah proses pembelajaran, kelembagaan pelaku utama perikanan seharunya merupakan media interaksi belajar antar pelaku utama dari anggota kelompoknya. Mereka dapat melakukan proses interaksi edukatif dalam rangka: mengadopsi teknologi inovasi; saling asah, asih dan asuh dalam menyerap suatu informasi dengan fasilitator atau pemandu dari penyuluh perikanan; mengambil kesepakatan dan tindakan bersama apa yang akan diambil dari sebuah kegiatan bersama. Didalam kelompok sebagai kelas belajar para pelaku utama akan dapat melakukan komunikasi multi dimensional. Mereka dapat mempertukarkan pengalaman masing-masing, sehingga akan membuat pelaku utama semakin dewasa untuk dapat keluar dari masalahnya sendiri, tanpa adanya ketergantungan dari penyuluh perikanan (Pranoto, 2006).

Sebagai wahana kerjasama, kelembagaan pelaku utama perikanan merupakan cerminan dari keberadaan suatu kelompok. Kelembagaan pelaku utama perikanan harus dapat berfungsi sebagai wadah kerjasama antar pelaku utama dalam upaya mengembangkan kelompok dan membina kehidupan pelaku utama. Kelompok pelaku utama perikanan sebagai unit produksi, erat hubungannya dengan fungsi wadah kerjasama. Misalnya kelompok pembudidaya ikan gurame, dalam pengadaan sarana produksi, perkreditan, dan pemasaran hasil, sehingga dengan melaksanakan kegiatan produksi secara bersama-sama akan lebih efisien dan efektif serta berhasilguna.

Tabel 4. Nilai Korelasi Faktor Internal kelompok Dengan Fungsi Kelompok.

\begin{tabular}{clccc}
\hline NO & \multicolumn{1}{c}{ FAKTOR INTERNAL } & $\begin{array}{c}\text { UNIT } \\
\text { BELAJAR }\end{array}$ & $\begin{array}{c}\text { FUNGSI KELOMPOK } \\
\text { UNIT } \\
\text { PRODUKSI }\end{array}$ & $\begin{array}{c}\text { UNIT USAHA } \\
\text { BERSAMA }\end{array}$ \\
\hline 1 & USIA KELOMPOK & 0,154 & 0,065 & 0,208 \\
2 & TINGKAT KELAS KELOMPOK & 0.039 & 0,029 & 0,164 \\
3 & JUMLAH ANGGOTA & 0.095 & 0,118 & 0,198 \\
\hline
\end{tabular}


Pada Tabel 5 memperlihatkan bahwa ddari ke 8 Unsur dinamika kelompok, unsur "tekanan pada kelompok" berhubungan erat dengan fungsi kelompok sebagai unir produksi. Artinya semakin tekanan pada kelompok tinggi dalam hal menghasilkan produksi untuk bisa sama dan melibihi kelompok lain akan semakin meningkatkan fungsi kelompok sebagai unit produksi yaitu menghasilkan produks sesuai dengan usaha yang dijalankan oleh kelompok, baik sebagai kelompok pembenih ikan yang menghasilkan benih ikan, maupun kelompok pembesaran ikan yang menghasilkan ikan konsumsi. Sedangkan unsur Keberhasilan kelompok ternyata berhubungan erat dengan berfungsi baiknya kelompok sebagai kelas belajar dan berhungan sangat erat pada unit kerjasama. Hal tersebut dapat dijelaskan bahwa pada kelompok-kelompok yang dibina dan unsur dinamika kelompok berupa keberhasilan kelompok ckup baik, maka fungsi kelompoknya akan berjalan dengan sangat baik pula.

Berkaitan dengan berfungsinya kelompok sebagai kelas belajar Hariadi (2011) mengemukakan bahwa faktor sikap anggota terhadap profesinya berpengaruh nyata terhadap keberhasilan kelompok sebagai unit belajar, dan juga yang berpangaruh adalah interkasi anggota yaitu andanya inetsitas komunikasi sehingga di antara para anggota dapat saling belajar bersama dan mengakibatkan kelompok sebagai berfungsi unit belajarnya.

Terkait dengan 4 (empat) fungsi kelompok seperti pada Tabel 5, Hariadi (2011) menyampaikan hasil penelitian bawa ada hubungan yang nyata antara fungsi unit belajar, unit kerjasama, unit produksi dan unit usaha. Semakin tinggi tingkat keberhasilan kelompok sebagai unit belajar berpengaruh meningkatkan keberhasilan kelompok sebagai unit kerjasama. Demikian pula, semakin tinggi tingkat keberhasilan kelompok sebagai unit kerjasama berpengaruh meningkatkan kedberhasilan kelompok sebagai unit produksi. Selanjutnya semakin tinggi tingkat keberhasilan kelompok sebagai unit produksi berpengaruh meningkatkan keberhasilan kelomook sebagai unit usaha.

Pada tabel 6. Dari delapan unsur dinamika kelompok hanya unsur" pengembangan dan pemeliharaan kelompok yang berhubungan erat dengan usia kelompok. Hal tersebut menunjukkan bahwa berkembangnya kelompok perikanan yang ada di Kabupaten Bekasi dipengaruhi atau sangat berhubungan dengan lamanya kelompok tersebut beridiri. Namun lamanya kelompok berdiri apabila tidak disertai dengan berjalannya fungsi kelomopok juga tidak akan menunjukkan perkembangan yang baik.

Tabel 5. Nilai Korelasi Unsur Dinamika Kelompok dengan Fungsi kelompok

\begin{tabular}{|c|c|c|c|c|}
\hline \multirow[b]{2}{*}{ No } & \multirow[b]{2}{*}{ UNSUR DINAMIKA KELOMPOK } & \multicolumn{3}{|c|}{ FAKTOR INTERNAL KELOMPOK } \\
\hline & & $\begin{array}{c}\text { USIA } \\
\text { KELOMPOK }\end{array}$ & $\begin{array}{c}\text { KELAS } \\
\text { KELOMPOK }\end{array}$ & $\begin{array}{l}\text { JUMLAH } \\
\text { ANGGOTA }\end{array}$ \\
\hline 1 & TUJUAN KELOMPOK & 0,205 & 0,088 & 0,253 \\
\hline 2 & STRUKTUR KELOMPOK & 0,233 & 0,300 & 0,029 \\
\hline 3 & FUNGSI TUGAS & 0,152 & 0,153 & 0,334 \\
\hline 4 & PENGEMBANGAN/PEMELIHARAAN KELOMPOK & $0,393^{*}$ & 0,102 & 0,151 \\
\hline 5 & KEKOMPAKAN ANGGOTA KELOMPOK & 0,019 & 0,093 & 0,175 \\
\hline 6 & SUASANA KELOMPOK & 0,194 & 0,042 & 0,138 \\
\hline 7 & TEKANAN PADA KELOMPOK & 0,124 & 0,199 & 0,232 \\
\hline 8 & KEBERHASILAN KELOMPOK & 0,109 & 0,043 & 0,071 \\
\hline
\end{tabular}

Ket: * nyata pada $0,05, * *$ nyata pada 0,01 
Tabel 6. Nilai Korelasi Unsur Dinamika Kelompok Dengan Faktor Internal Kelompok

\begin{tabular}{|c|c|c|c|c|}
\hline \multirow[b]{2}{*}{ No } & \multirow[b]{2}{*}{ UNSUR DINAMIKA KELOMPOK } & \multicolumn{3}{|c|}{ FUNGSI KELOMPOK } \\
\hline & & KELAS & $\begin{array}{l}\text { UNIT } \\
\text { PRODUKST }\end{array}$ & UNIT USAHA \\
\hline 1 & TUJUAN KELOMPOK & 0,060 & 0,069 & 0,150 \\
\hline 2 & STRUKTUR KELOMPOK & 0,103 & 0,179 & 0,198 \\
\hline 3 & FUNGSI TUGAS & 0,023 & 0,187 & 0,157 \\
\hline 4 & $\begin{array}{l}\text { PENGEMBANGAN/PEMELIHARAAN } \\
\text { KELOMPOK }\end{array}$ & 0,092 & 0,270 & 0,058 \\
\hline 5 & KEKOMPAKAN ANGGOTA KELOMPOK & 0,202 & 0,158 & 0,175 \\
\hline 6 & SUASANA KELOMPOK & 0,246 & 0,296 & 0,288 \\
\hline 7 & TEKANAN PADA KELOMPOK & 0,196 & $0,378^{*}$ & 0,139 \\
\hline 8 & KEBERHASILAN KELOMPOK & $0,400^{*}$ & $0,771^{* *}$ & 0,290 \\
\hline
\end{tabular}

Sedangkan usur dinamika kelompok lainnya tidak begitu erat hubunganya dengan berfungsi atau belum berfungsi baiknya suatu kelompok perikanan.

Pada tabel 7 memperlihatkan bahwa tujuan kelompok berhubungan sangat erat dengan struktur kelompok dan unsur pengembangan dan pemeliharaan kelompok. Hal ini bisa dijelaskan bahwa kelompok yang memilkiki tujuan yang jelas akan berdampak pada terbentuknya struktur kelompok yang baik dan benar, dan akan sangat erat dalam pengembangan kelompok tersebut. Oleh karena itu dalam pembinaan kelompok membimbing musyawarah kelompok untuk mennentukan tujuan baik jangka pendek, jangka menengah dan jangka panjang sangat penting. Struktur kelompok yang baik dan benar juga akan berhubungan sangat erat dengan terjadinya kekompakan kelompok dalam menjalankan fungsi-fungsi kelompoknya. Struktur kelompok akan terbentuk dengan baiki apabila dalam pembentukannya dilakukan atas dasar musyawarah para anggota sehingga menghasilankan kepemimpinan yang membawa keberhasilan kelompok. Sedangkan unsut pengembangan kelompok berhubungan erat dengan terbentuknya suasana kelompok yang kondusif.

Pengembangan kelompok bukan hanya sekedar menaikan kelas kelompok saja, namun yang lebih penting adalah unsur-unsur dalam

Tabel 7. Nilai Korelaski antar Unsur Dinamika Kelompok

\begin{tabular}{|c|c|c|c|c|c|c|c|c|c|}
\hline \multirow[t]{2}{*}{ NO } & \multirow[t]{2}{*}{ UNSUR DINAMIKA KELOMPOK } & \multicolumn{8}{|c|}{ UNSUR DINAMIKA KELOMPOK } \\
\hline & & (1) & (2) & (3) & (4) & $(5)$ & (6) & (7) & (8) \\
\hline 1. & TUJUAN KELOMPOK & 1 & $0,379^{* *}$ & 0,301 & $0,503^{* \star}$ & 0,357 & 0,281 & 0,231 & 0,060 \\
\hline 2. & STRUKTUR KEIOMPOK & & 1 & 0,081 & 0,309 & $0,531^{* *}$ & 0,242 & 0,056 & 0,103 \\
\hline 3. & FUNGSI TUGAS & & & 1 & 0,095 & 0,066 & 0,091 & 0,102 & 0,273 \\
\hline 4. & $\begin{array}{l}\text { PENGEMBANGAN PEMEIHARAAN } \\
\text { KELOMPOK }\end{array}$ & & & & 1 & 0,289 & $0,422^{*}$ & 0,314 & 0,251 \\
\hline 5. & KEKOMPAKAN ANGGOTA KELOMPOK & & & & & 1 & 0,295 & 0,250 & 0,193 \\
\hline 6. & SUASANA KELOMPOK & & & & & & 1 & 0,307 & 0,102 \\
\hline 7. & TEKANAN PADA KELOMPOK & & & & & & & 1 & 0,344 \\
\hline 8. & KEBERHASILAN KELOMPOK & & & & & & & & 1 \\
\hline
\end{tabular}

Ket: * Siginifikan pada level 0,05,** Signifikan pada level 0,01 
setiap kelas kelompok benar-benar berjalan sacara nyata. Hal tersebut harus dijalankan ketika dilakukan penilaian kelas kelompok, bukan hanya sekedar administrasi dan guguir kewajiban, namum harus terdata mana unsur yang sudah beerjalan dengan baik dan perlu dipertahankan, dan unsur mana yang perlu poembinaan lebih lanjut, sehingga bisa menaikan kelas kelompok.

Pada Tabel 8. Menunjukkan bahwa bila kelompok sebagai unit usaha bersama berfungsi dengan baik, maka fungsi sebagai kelas belajarpun akan berfungsi dengan baik, dan demikian sebaliknya. Sedangkan fungsi kelompok yang lain tetap masih ada hubungan yang timbal balik namum pada kasusu kelompok perikanan di Kabupoaten bekasi belum memperlihatkan keeratan yang kuat antar fungsi kelompok sebagai kelas belajar dengan sebagai unit produksi. Terkati dengan fungsi kelompok Hariadi (2011) menjelaskan bahwa meningkatnya kerjasama di dalam kelompok (pengadaan saprokan, pemasaran, pengolahan) berpengaruh meningkatkan produksi. Demikian pula peningkatan kerjasama terutama dengan luar kelompok (koperasi, bank, kelompok lain) berpengaruh meningkatkan usaha kelompok sehinggga usaha kelompok berkembang (bukan hanya peningkatan produksi).

\section{Kesimpulan dan Saran}

Kesimpulan

1. Umur kelompok perikanan yang ada di Kabupaten Bekasi relatif masih muda yaitu rata-rata baru 3,7 tahun dengan kelas kelompok rata-rata madya, dan jumlah anggota relatif cukup yaitu 25 oanggota per kelompok

2. Ke delapan unsur dinamika kelompok pada 53,4\% sampai 93,3\% pada katagori cukup, yang pada katagori tinggi hanya 23,3\% yaitu pada unsur tekanan pada kelompok.

3. Fungsi kelompok persentase tertinggi pada katagori sedang (60-87\%), pada katagori tinggi hanya $10 \%$ pada fungsi unit usaha bersama, sedang pada unit kelas belajar dan nunit produksi tidak ada katagori tinggi.

4. Nilai korelasi faktor internal kelompok tidak yang berhubungan erat dengan fungsi kelompok

5. Unsur dinamika kelompok yang berhubungan erat dengan fungsi kelompok yaitu unsur tekanan pada kelompok dan keberhasilan kelompok, sedangkan yang berkorelasi kuat dengan faktor internal kelompok pada unsur

Tabel 8. Nilai Korelasi Antar Fungsi kelompok

\begin{tabular}{|llccc|}
\hline NO & UNSURDINAMIKA KELOMPOK & \multicolumn{3}{c|}{ FUNGSIKELOMPOK } \\
& & KELAS BELAJAR & UNIT PRODUKSI & UNIT USAHA BERSAMA \\
\hline 1. & KELAS BELAJAR & 1 & 0,354 & $\mathbf{0 , 8 7 9 ^ { * * }}$ \\
2. & UNIT KERJASAMA & 0,354 & 1 & 0,311 \\
3. & UNIT USAHA BERSAMA & $\mathbf{0 , 8 7 9 ^ { * * }}$ & 0,311 & 1 \\
\hline
\end{tabular}

Ket; * Signifikan pada level 0,05, ** Signifikan pada level 0,01 
1. Pembinaan terhadap unsur-unsur dinamika kelompok sangat penting dalam upaya peningkatan fungsi kelompok

2. Pemahaman tentang unsur dinamika kelompok dan fungsi kelompok oleh anggota kelompok sangat penting dalam peningkatan produktivitas kelompok.

\section{Daftar Pustaka}

2008. Per Men Pan 192008 Jabatan Penyuluh Perikanan dan Angka Kreditnya.

2011. Per Men KP no. 14/2011 Pedoman Penumbuhan Kelambagaan Pelaku Utama Perikanan.

Anonimous. 2006. Undang-Undang Sistem Penyuluhan Pertanian, Perikanan dan Kehutanan, Nomor 16. Tahun 2006.

Hariadi, SS. 2000. Dinamika Kelompok Tani dalam Pembangunan Pertanian. Yogyakarta; Fakultas Pertanian UGM.

Hariadi, SS, 2011. Dinamika kelompok. Teori dan Aplikasi untuk Analisis Keberhasilan Kelompok Tani sebagai Unit Belajar, Kerjasama, Produksi dan Bisnis. Pasca Sarjana. UGM.

Pranoto, J dan Suprapti, W. 2006. Membangun Kerjasama Tim (Team Building). Lembaga Administrasi Negara Republik Indonesia, Jakarta.

Mardikanto. T, 1993. Penyuluhan Pembangunan Pertanian. Sebelas Maret University Press, Surakarta.

Margono Slamet, 1989. “Kumpulan Bacaan Penyuluhan Pertanian”. Institut Pertanian Bogor.

Kerlinger, F.N., 2002. Asas-asas Penelitian Behavioral. Diterjemahkan landing $R$. Simatupang. Yogyakarta: Gajah mada University Press.

Rogers, E.M. \& FF Shoemaker. 1987. Memasyarakatkan Ide-Ide baru. Disarikan oleh Abdillah hanafi. Surabaya: Usaha Nasional. 